\title{
Insights from the sequence similarity of Zika virus proteins with the Human nerve proteins
}

\author{
Prasanna Marsakatla1, Sujai Suneetha1, Joshua Lee², Paari Dominic Swaminathan ${ }^{3}$, Logeshwaran \\ Vasudevan ${ }^{4}$, Rachael Supriya ${ }^{1}$, Lavanya Moses Suneetha ${ }^{1 *}$
}

Received April 10, 2018; Revised April 23, 2018; Accepted April 30, 2018; Published May 31, 2018

${ }^{1}$ CODEWEL Nireekshana ACET, Narayanaguda, Hyderabad -500029, Telangana, India; ${ }^{2}$ York University, Department of Science, 4700 Keele St, Toronto, ON M3J 1P3, Canada; ${ }^{3}$ LSU Health Sciences Center, Center for Cardiovascular Diseases and Sciences Shreveport, LA, USA; 4Presidency College, Department of Zoology, Chennai-05, India; Lavanya Moses Suneetha - E:mail drlavanyasuneetha@gmail.com; Phone: +91-40-23221033; +91-9885150381; *Corresponding Author

\section{doi:10.6026/97320630014194}

\begin{abstract}
:
Massive peptide sharing between the Zika virus polyprotein and host tissue proteins could elicit significant host-pathogen interactions and cross-reactions leading to autoimmune diseases. This study found similarities in the Zika V proteins and human nerve tissue proteins. 63 human nerve proteins were screened for similarities with the Zika V of which Neuromodulin, Nestin, Galanin, Bombesin, Calcium-binding protein were found to have similarities to the Zika V poly protein $\mathrm{C}$ at different sequence regions. These sequence similarities could be significant in regulating pathogenic interactions/autoimmunity, as Polyprotein $\mathrm{C}$ is known to be a virulent factor.
\end{abstract}

Keywords: Zika V, Nerve tissue proteins, Neuropathogenesis, Bioinformatics, BLAST, Neuromodulin, Nestin, Bombesin, Galanin, Calcium-binding protein.

\begin{abstract}
Background:
The Zika Virus (Zika V), is an emerging infectious disease agent causing human birth defects. It has created a global alarm and was declared a public health emergency of international concern by the World Health Organization (WHO) [1]. The Zika V proteome has been sequenced. Its role in infection, inflammation and pathogenesis of the human nerve are being extensively investigated. Recent studies have revealed that the Zika V shows preferential infection to neural progenitor cells of a mouse brain and when it infects the neural stem cells and immature neurons, results in alterations in the gene expression of cell cycle related proteins inducing neural-cell death and reduced production of new neurons. The decreased proliferation of the neural cells could cause fetal microcephaly in infected pregnant women $[2,3]$. Selective permeability permitting the Zika V to cross the foetal blood-brain barrier has also been indicated $[4,5]$. Acute infection in these patients leads to a polyfunctional T-cell activation along with increased response of its respective cytokines (IL-1 $\beta$, IL-2, IL-4, IL-6, IL-9, IL-13, IL-17, IFN- $\gamma$ ) and growth factor responses [RANTES, macrophage inflammatory protein $1 \alpha(\mathrm{MIP} 1 \alpha)$ and vascular endothelial growth factor response (VEGF)] [6]. Research on the various cells targeted by the Zika V revealed the engagement of several host adhesion factors (DC-SIGN, AXL, ISSN 0973-2063 (online) 0973-8894 (print)
\end{abstract}

Bioinformation 14(5): 194-200 (2018)
Tyro3, and TIM-1) facilitating the entry of the Zika V into different tissue cells [7]. Cell culture experiments of the Zika V infection expressed transcription of Toll-like receptor 3 (TLR3), retinoic acid-inducible gene 1 (RIG-I) and melanoma differentiation-associated protein 5 (MDA5) [7].

The molecular mechanism of the pathogen's interaction with the host and its use in drug discovery is at an experimental stage [8, 9]. Though the pathogenic pathway of infectious agents across various host tissues is distinctive and often undefined, many of these processes can be attributed to a role of molecular mimicry between pathogen and its corresponding host tissue proteins [10, 11]. A study identified the sequence and structural similarities between Mycobacterium leprae and the immunoglobulin regions of Myelin P0, which could be the contributing factor to autoimmunity to myelin P0 amongst Leprosy patients with peripheral nerve damage [12-15]. The sequence and structural similarities between the Zika V Virulant Factor and host nerve peptides could directly or indirectly impact the pathogenesis of the disease [16]. There is insilco evidence revealing massive peptide sharing between the Zika $\mathrm{V}$ protein and host tissue proteins causing cross-reactions inducing autoimmunity. Recent research demonstrated reveals the expression of unique 
transcriptomic signatures in Zika V infected human neural stem cells $[17,18]$.

However, to the best of our knowledge there is no report on major human nerve tissue protein similarities to the Zika $\mathrm{V}$ proteins. The hypothesis is that sequence and structural similarities (mimics) that exist in the host nerve and pathogen proteins include significant host-pathogen cross reactions - i.e. in receptor binding, steric hindrance, signalling/transmission, metabolic alteration, inflammation and auto-antibody production, which could ultimately lead to aberrant development of neurons and neuropathy $[\mathbf{1 9}, \mathbf{2 0}]$. To assess whether such sequence similarities / molecular mimics occurred between the Zika $\mathrm{V}$ and the human host, we compared the peptide sequence of 63 proteins expressed in the human nerve tissue with that of the peptide sequence of the Zika V polyprotein with the use of bioinformatic tools.

\section{Methodology:}

64 human nerve proteins were selected to be BLAST (Basic Local Alignment Search Tool; Version 2.2.28; e-value $\leq 0.01$ ) against the Zika V proteome (Tax ID 64320). The peptide sequence similarities between the host and counterpart proteins were identified in the PSI-Blast (BLASTP 2.6.0+) by their aa/nucleotide positions [21].

\section{Selection of nerve proteins:}

64 proteins (Table 1) that were enriched and enhanced in the nervous tissue demonstrated by immunohisochemistry were extracted from the Human Protein Atlas Database (www.proteinatlas.org). FASTA formats for each of the above proteins were retrieved from NCBI PubMed and were saved in a Microsoft notepad to be BLAST against the Zika V proteome (Tax ID 64320). The output of the BLAST identified significant peptide sequence similarities between the human protein and its pathogen counterpart. Similarities identified in the peptide sequence region of Neuromodulin was superimposed on the of the viral protein Cryo-em structure of the immature Zika V structure (PDB ID: 5U4W_A) using the Visual Molecular Dynamics 1.9.1 (VMD) modelling software.

\section{Results:}

Nestin, Bombesin, Galanin, Calcium Binding Protein and Neuromodulin were found to mimic the Cryoem- protein and various other peptide regions of the polyprotein $\mathrm{C}$ in the Zika V proteome.

Table 1: List of nerve proteins used in the analysis

\begin{tabular}{|c|c|c|c|c|c|}
\hline S. No & Proteins & Protein Code & S. No & Proteins & Protein Code \\
\hline 1 & Agrin & AGRN, O00468 & 33 & Probable tubulin polyglutamylase & TTLL1,O95922 \\
\hline 2 & Calbindin & CALB1,P05937 & 34 & Myelin basic protein & MBP,P02686 \\
\hline 3 & N-chimaerin & CHIN,P15882 & 35 & Protein phosphatase 1 regulatory subunit $1 \mathrm{~B}$ & PPR1B,Q9UD71 \\
\hline 4 & Secretogranin-2 & SCG2,P15882 & 36 & $\begin{array}{l}\text { Arf-GAP with GTPase, ANK repeat and PH domain- } \\
\text { containing protein } 2\end{array}$ & AGAP2,Q99490 \\
\hline 5 & Neuromodulin & NEUM,P13521 & 37 & Cathepsin L2 & CATL2,O60911 \\
\hline $\begin{array}{l}6 \\
7\end{array}$ & $\begin{array}{l}\text { Kinesin } \\
\text { Tau protein }\end{array}$ & $\begin{array}{l}\text { KIFC1,P17677 } \\
\text { TAU,P10636 }\end{array}$ & $\begin{array}{l}38 \\
39\end{array}$ & $\begin{array}{l}\mathrm{D}(1 \mathrm{~A}) \text { dopamine receptor } \\
\text { BDNF/NT-3 growth factors receptor }\end{array}$ & $\begin{array}{l}\text { DRD1,P21728 } \\
\text { NTRK2,Q16620 }\end{array}$ \\
\hline $\begin{array}{l}8 \\
9\end{array}$ & $\begin{array}{l}\text { 2',3'-cyclic-nucleotide 3'-phosphodiesterase } \\
\text { Myelin-associated glycoprotein }\end{array}$ & $\begin{array}{l}\text { CN37,P09543 } \\
\text { MAG,P20916 }\end{array}$ & $\begin{array}{l}40 \\
41\end{array}$ & $\begin{array}{l}\text { Melanoma-associated antigen E1 } \\
\text { Microtubule-associated protein } 6\end{array}$ & $\begin{array}{l}\text { MAGE1,Q9HCI5 } \\
\text { MAP6,Q96JE9 }\end{array}$ \\
\hline $\begin{array}{l}10 \\
11\end{array}$ & $\begin{array}{l}\text { Myelin protein P0 } \\
\text { Myelin P2 protein }\end{array}$ & $\begin{array}{l}\text { MYP0,P25189 } \\
\text { MYP2,P02689 }\end{array}$ & $\begin{array}{l}42 \\
43\end{array}$ & $\begin{array}{l}\text { Protocadherin alpha- } 12 \\
\text { Carboxypeptidase E }\end{array}$ & $\begin{array}{l}\text { PCDAC,Q9UN75 } \\
\text { CBPE,P16870 }\end{array}$ \\
\hline $\begin{array}{l}12 \\
13\end{array}$ & $\begin{array}{l}\text { Oligodendrocyte-myelin glycoprotein } \\
\text { Brain-derived neurotrophic factor }\end{array}$ & $\begin{array}{l}\text { OMGP,P23515 } \\
\text { BDNF,P23560 }\end{array}$ & $\begin{array}{l}44 \\
45\end{array}$ & $\begin{array}{l}\text { Down syndrome cell adhesion molecule } \\
\text { Dyslexia-associated protein KIAA0319 }\end{array}$ & $\begin{array}{l}\text { DSCAM,O60469 } \\
\text { K0319,Q5VV43 }\end{array}$ \\
\hline $\begin{array}{l}14 \\
15 \\
16\end{array}$ & $\begin{array}{l}\text { Ciliary neurotrophic factor } \\
\text { Neurotrophin-3 } \\
\text { Beta-nerve growth factor }\end{array}$ & $\begin{array}{l}\text { CNTF,P26441 } \\
\text { NTF3,P20783 } \\
\text { NGF,P01138 }\end{array}$ & $\begin{array}{l}46 \\
47 \\
48\end{array}$ & $\begin{array}{l}\text { Uncharacterized protein KIAA1211-like } \\
\text { Microtubule-associated protein 1B } \\
\text { Neuronal calcium sensor } 1\end{array}$ & $\begin{array}{l}\text { K121L,Q6NV74 } \\
\text { MAP1B,P46821 } \\
\text { NCS1,P62166 }\end{array}$ \\
\hline $\begin{array}{l}17 \\
18\end{array}$ & $\begin{array}{l}\text { Nestin } \\
\text { Neurofilament heavy polypeptide }\end{array}$ & $\begin{array}{l}\text { NEST,P48681 } \\
\text { NFH,P12036 }\end{array}$ & $\begin{array}{l}49 \\
50\end{array}$ & $\begin{array}{l}\text { Neurofilament light polypeptide } \\
\text { Receptor expression-enhancing protein } 2\end{array}$ & $\begin{array}{l}\text { NFL,P07196 } \\
\text { REEP2,Q9BRK0 }\end{array}$ \\
\hline $\begin{array}{l}19 \\
20\end{array}$ & $\begin{array}{l}\text { Neurogranin } \\
\text { Voltage-dependent T-type calcium channel } \\
\text { subunit alpha-1G }\end{array}$ & $\begin{array}{l}\text { NEUG,Q92686 } \\
\text { CAC1G,O43497 }\end{array}$ & $\begin{array}{l}51 \\
52\end{array}$ & $\begin{array}{l}\text { Secretogranin-3 } \\
\text { Ubiquitin carboxyl-terminal hydrolase isozyme L1 }\end{array}$ & $\begin{array}{l}\text { SCG3,Q8WXD2 } \\
\text { UCHL,P09936 }\end{array}$ \\
\hline 21 & Hippocalcin & HPCL1,P37235 & 53 & $\begin{array}{l}\text { Galactosylgalactosylxylosylprotein 3-beta- } \\
\text { glucuronosyltransferase } 1\end{array}$ & B3GA1,Q9P2W7 \\
\hline 22 & Neurocalcin-delta & NCALD,P61601 & 54 & Beta-1,4 N-acetylgalactosaminyltransferase 1 & B4GN1,Q00973 \\
\hline 23 & Recoverin & RECO,P35243 & 55 & Caprin-2 & CAPR2,Q6IMN6 \\
\hline $\begin{array}{l}24 \\
25\end{array}$ & $\begin{array}{l}\text { Bombesin receptor subtype-3 } \\
\text { Kininogen-1/Bradykinin }\end{array}$ & $\begin{array}{l}\text { BRS3,P32247 } \\
\text { KNG1,P01042 }\end{array}$ & $\begin{array}{l}56 \\
57\end{array}$ & $\begin{array}{l}\text { Dopamine beta-hydroxylase } \\
\text { Protein FAM81A }\end{array}$ & $\begin{array}{l}\text { DOPO,P09172 } \\
\text { FA81A,Q8TBF8 }\end{array}$ \\
\hline $\begin{array}{l}26 \\
27\end{array}$ & $\begin{array}{l}\text { Calcitonin } \\
\text { Cholecystokinin }\end{array}$ & $\begin{array}{l}\text { CALC,P01258 } \\
\text { CCKN,P06307 }\end{array}$ & $\begin{array}{l}58 \\
59\end{array}$ & $\begin{array}{l}\text { Mitogen-activated protein kinase } 10 \\
\text { N-terminal EF-hand calcium-binding protein } 1\end{array}$ & $\begin{array}{l}\text { MK10,P53779 } \\
\text { NECA1,Q8N987 }\end{array}$ \\
\hline 28 & Galanin peptides & GALA,P22466 & 60 & Neuroligin-3 & NLGN3,Q9NZ94 \\
\hline 29 & Pro-neuropeptide $Y$ & NPY,P01303 & 61 & $\begin{array}{l}\text { Protein kinase } C \text { and casein kinase substrate in neurons } \\
\text { protein } 1\end{array}$ & PACN1,Q9BY11 \\
\hline 30 & Neurotensin/neuromedin $\mathrm{N}$ & NEUT,P30990 & 62 & Sodium channel protein type 7 subunit alpha & SCN7A,Q01118 \\
\hline 31 & Protein S100-B & S100B,P04271 & 63 & Clathrin coat assembly protein AP180 & AP180,060641 \\
\hline 32 & Synapsin-1 & SYN1,P17600 & & & \\
\hline
\end{tabular}




\section{BIOINFORMATION \\ Discovery at the interf face of physical and biological sciences}

\section{Open access}

Sequence similarity of Neuromodulin peptide on ZIKV polyprotein C:

Neuromodulin had a peptide sequence similarity to that of the present in the Cryo-em immature Zika V Protein Data Bank PDB. ID: 5U4W_A peptide sequence, which forms a part of polyprotein (Figure 1). The similarity of peptide region from 182 to 203 positions 'ELTGYGTVTMECSPRT' of Neuromodulin with Zika V protein has been superimposed and structurally modelled (Figure 2).

Sequence similarity of Nestin to Zika V polyprotein: Nestin was identified to have sequence similarities to the Zika V polyprotein (Sequence ID: AMM43326.1) Amino acid range: 3097 to 3215 position by BLAST results (Figure 3).

Sequence similarity of Bombesin to Zika $\mathrm{V}$ polyprotein: Bombesin was identified to have sequence similarities with polyprotein Zika V (Sequence ID: ANK57896.1) Amino acid range: 62 - 147 position (Figure 4).

\section{Alianments}

Chain A, Cryo-em Structure Of Immature Zika Virus

Sequence ID: 5U4W_A Length: 402 Number of Matches: 1

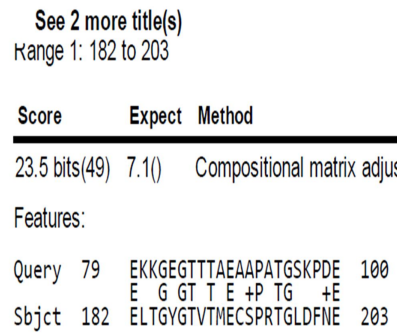

Figure 1: Neuromodulin similarity region in Chain A, Cryo-em Structure of Immature Zika V, Sequence ID: 5U4W_A Length: 402 Number of Matches: 1,Range 1: 182 to 203, Score: 23.5 bits (49), Expect: 7.1, Method: Compositional matrix adjust, Identities: 10/22(45\%), Positives: 12/22(54\%), Gaps: 0/22(0\%).

Sequence similarity of Galanin to Zika V polyprotein: Galanin was identified to have similarities with the polyprotein partial Zika V (Sequence ID: ANF29038.1) Amino acid range: 440 - 476 position (Figure 5).

Sequence similarity of Calcium-binding protein to Zika V: polyprotein: Calcium Binding Proteins (CaBPs) were identified to have similarity with polyprotein Zika V (Sequence ID: AHF49785.1). Amino acid range: 2872 to 2967 position (Figure 6). Multiple sequence alignments were carried out for polyprotein C with Neuromodulin, Nestin, Bombesin, Galanin and Calcium-binding protein. Multiple sequence similarities were found in a broad region of amino acids 900 -3320 [23] (Figure 7). Comparative similarity percentages of Zika V polyprotein $\mathrm{C}$ with human proteins are shown in Table 2.

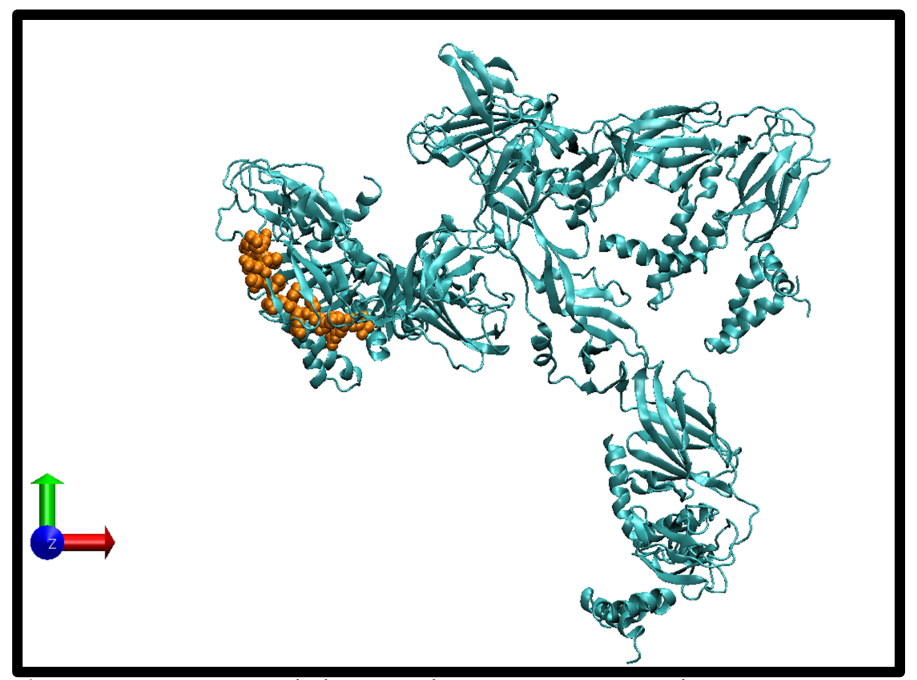

Figure 2: Neuromodulin similarity region in Chain A, Cryo-em Structure of Immature Zika V. The yellow chain of amino acids (ELTGYGTVTMECSPRT) is located on the ribbon model of 5U4W_A an output of VMD (Visual Molecular Dynamics) on the $\mathrm{N}$-terminal side of the molecule.

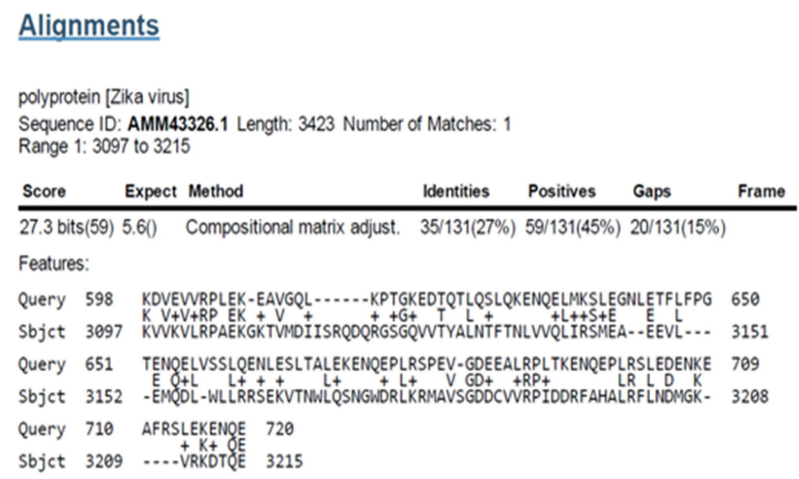

Figure 3: Nestin similarity region in polyprotein [Zika V], Sequence ID: AMM43326.1, Length: 3423, Number of Matches: 1, Range 1: 3097 to 3215, Score: 27.3 bits (59), Expect: 5.7, Method: Compositional matrix adjust, Identities: 35/131(27\%), Positives: 59/131(45\%), Gaps: 20/131(15\%).

\section{Discussion:}

Bioinformatics is an exciting; exploratory method for peptide discovery towards the development of antimicrobial therapies and vaccination strategies [24]. The approach to identifying the similarities between host cell-viral proteins has now become facile with the extensive genomic and protein databases that exist [25]. The present study selected 63 human nerve proteins of which peptides of the Neuromodulin, Nestin, Bombesin, Galanin and Calcium-binding protein were found to have mimics with the Zika $\mathrm{V}$ proteins. The study discovered multiple similarity regions in polyprotein $\mathrm{C}$ of $\mathrm{Zika} \mathrm{V}$. This approach was different from the earlier published method, which selected pentapeptide epitopes in the human proteome database and BLAST against the Zika $\mathrm{V}$ proteome sequence. A vast number of pentapeptide matching/mimics was observed which were putative epitopes 
for autoimmunity. Our data strengthened the hypothesis of host autoimmunity due to the sequence and structural mimics of the Zika V with host peptides larger than pentapeptide [19]. In addition to causing autoimmunity in the host, the similarities could also have an influence on other metabolic pathways of the host cell. Human nerve protein Neuromodulin is a component of the motile growth cones. It is a membrane protein whose expression is widely correlated with nerve growth (axon elongation and effective regeneration response) [26]. Although the biological role of Neuromodulin is undetermined, the Nterminal region contains a calmodulin binding domain, sites for fatty acylation, membrane attachment and a protein kinase $\mathrm{C}$ phosphorylation site (Uniprot Data). A structural prediction of the C-terminal region suggests similarities to the side arms of neurofilaments, which could ultimately have a role in the formation of a dynamic membrane-cytoskeleton-calmodulin complex [27]. The sequence similarities identified in Zika V and Neuromodulin could alter membrane signal transduction and function of neurofilaments in the neuron, influence viral replication and further impair the immune surveillance system.

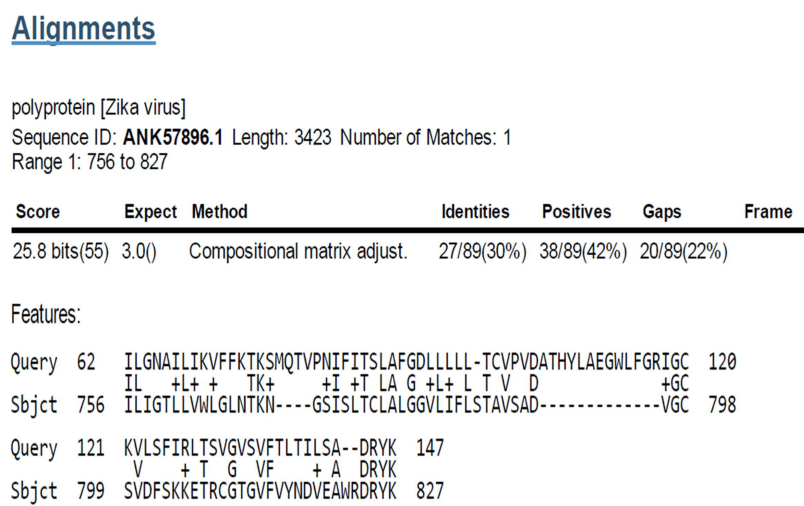

Figure 4: Bombesin similarity region in polyprotein [Zika V], Sequence ID: ANK57896.1, Length: 3423, Number of Matches: 1, Range 1: 756 to 827 . Score: 25.8 bits (55), Expect: 3.0, Method: Compositional matrix adjust, Identities: 27/89(30\%), Positives: 38/89(42\%), Gaps: 20/89(22\%).

Nestin an intermediate filament protein is a stem cell marker expressed in the development of the central nervous system [28]. Nestin's similarity with polyprotein C of the Zika V could play a role in the pathogenesis of Zika V in the fetal brain. The similarity of Nestin with RNA-directed RNA polymerase (NS5) protein of the Zika V could influence host-pathogen interactions specifically encouraging viral proteome replication. It could also prevent the establishment of the cellular antiviral state by blocking the interferon-alpha/beta (IFN-alpha/beta) signalling pathway, inhibiting host TYK2 and STAT2 phosphorylation; thereby preventing activation of the JAK-STAT signalling pathway and to immune evasion [28].

Galanin is a peptide, which functions as a hormone that regulates the neuromodulation in the central and peripheral nervous systems. It is localised in neurosecretory granules and it could also function as a neurotransmitter. It has been shown to coexist with other peptide and amine neurotransmitters within individual neurons $[30,31]$. The Galanin that shows similarity with the Zika V proteome is Envelope protein E. This protein is responsible for binding to host cell surface receptors and mediates fusion between viral and cellular membranes. Galanin peptides are associated with depression in Alzheimer's and the similarities of Galanin to Zika V polyprotein could be Zika V associated depression $[32,33]$.

\section{Alianments}

\section{polyprotein, partial [Zika virus]}

Sequence ID: ANF29038.1 Length: 936 Number of Matches: 1

Range 1: 440 to 476

Score Expect Method Identities Positives Gaps Frame

23.9 bits(50) 2.3() Compositional matrix adjust. $\quad 14 / 47(30 \%)$ 23/47(48\%) $10 / 47(21 \%)$

Features:

Query 53 SFSDKNGLTSKRELRPEDDMKPGSFDRSIPENNIMRTIIEFLSFLHL 99 Sbjct 440 SFRAKDGCWVGMEIRP ...........RKEPESNLVRSNUTAGSTDHM 476

Figure 5: Galanin similarity region in polyprotein, partial [Zika V], Sequence ID: ANF29038.1, Length: 936, Number of Matches: 1, Range 1: 440 to 476. Score 23.9 bits (50), Expect 2.3, Method: Compositional matrix adjust, Identities: 14/47(30\%), Positives: 23/47(48\%), Gaps: 10/47(21\%).

\section{Alianments}

polyprotein [Zika virus]

Sequence ID: AHF49785.1 Length: 3422 Number of Matches: 1 Range 1: 2872 to 2967

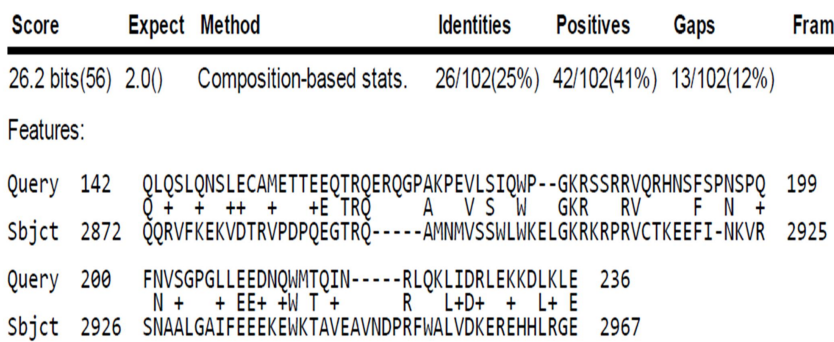

Figure 6: Calcium binding protein similarity region in polyprotein [Zika V], Sequence ID: AHF49785.1, Length: 3422, Number of Matches: 1, Range 1: 2872 to 2967Score: 26.2 bits (56), Expect: 2.0, Method: Composition-based stats, Identities: 26/102(25\%), Positives: 42/102(41\%), Gaps: 13/102(12\%). 


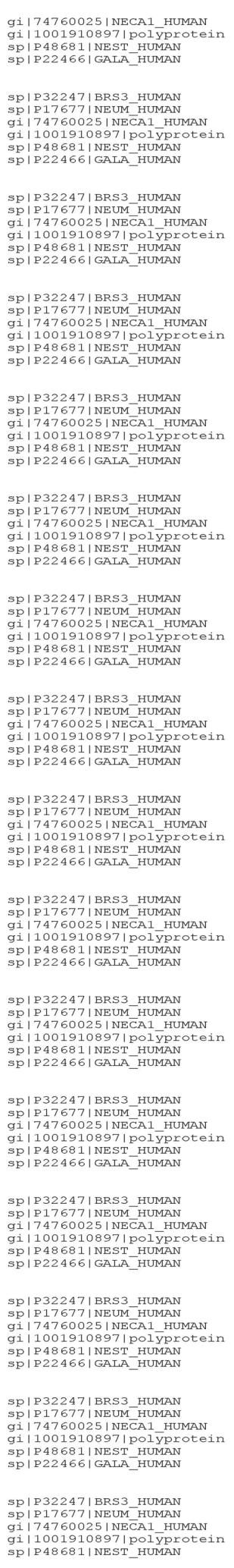

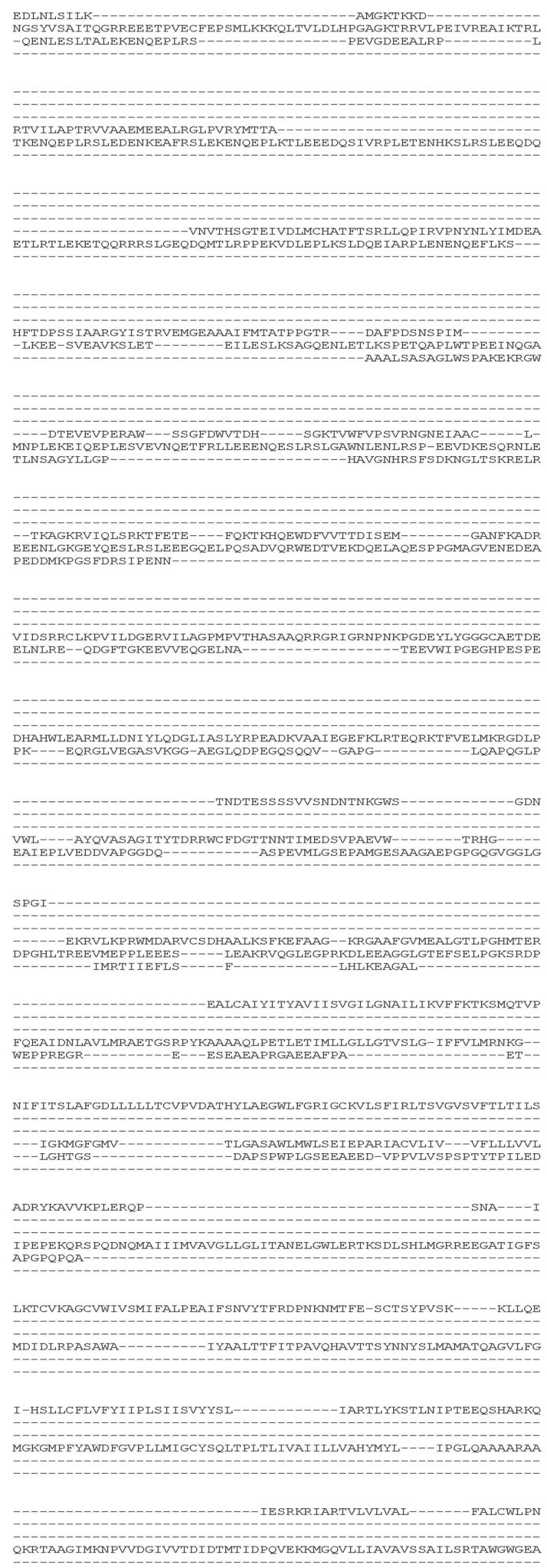

QKRTAAGIMKNPVVDGIVVTDIDTMTIDPQVEKKMGQVLIIAVAVSSAILSRTAWGWGEA

Figure 7: The segment of Zika virus polyprotein C (1659-2464 aa) that shows sequence similarities in multiple sequence alignment of human proteins. The sequences of polyprotein $C$ were aligned with bombesin, neuromodulin, calcium binding protein, nestin and galanin using CLUSTAL O (1.2.4) for multiple sequence alignment. 


\section{Open access}

Bombesin-like peptides are a large family, which are localised in CNS. In Xenopus laevis, the highest number of Bombesin binding sites was present in the brain and has a regulatory role in energy metabolism [29]. The similarity of the Zika V polyprotein with Bombesin could influence the energy metabolism of the fetal brain.

Calcium Binding Proteins (CaBPs are related to Calmodulins) are localised in the brain and sensory organs. They are an important components of $\mathrm{Ca}(2+)$ mediated cellular signal transduction, excitation-contraction coupling in muscle, neurotransmitter and hormone release and Ca2+-dependent gene transcription Calcium is the key element of adequate neuronal function in the body. The CaBP family regulates effectors such as voltage-gated $\mathrm{Ca} 2+$ channels in a Ca2+-dependent manner [34-36]. The similarity of the Zika V polyprotein with CaBP could have an interaction affecting the neuronal cell function.

All of the five nerve proteins Neuromodulin, Nestin, Galanin, Bombesin, Calcium binding protein had similarities to the Polyprotein C (3423 aa length) of the Zika V. Polyproteins [http://www.uniprot.org/ uniprot/Q32ZE] are a subgroup of non-structural major viral proteins (NSP) which are highly significant (prM, RNA-directed RNA polymerase NS5, NSP, 2A, 2B, 4A, 4B, Serine protease NS3, Peptide 2kPCBPs) in virus budding by attachment to the host cell membrane, gathering viral RNA into a nucleo-capsid to form the core of a mature virus particle within the host. During viral entry into the cell, the polyprotein induces genome penetration in host cytoplasm and migration into host cell nucleus where it modulates host functions [37]. The similarities identified in Nestin, Bombesin, Galanin, Calcium Binding Protein and Neuromodulin to their counterpart polyprotein C in ZIKV could help us identify peptide sequences which can regulate host cell [38].

Table 2: Comparative similarity percentages of Zika V polyprotein $\mathrm{C}$ with human proteins.

\begin{tabular}{|c|c|c|c|c|c|}
\hline $\begin{array}{l}\text { S. } \\
\text { No }\end{array}$ & $\begin{array}{l}\text { Human } \\
\text { Protein }\end{array}$ & $\begin{array}{l}\text { Viral } \\
\text { Protein }\end{array}$ & $\begin{array}{l}\text { Sequence ID } \\
\text { Zika V } \\
\text { Polyprotein }\end{array}$ & $\begin{array}{l}\text { Similarity } \\
\text { Region Zika V } \\
\text { Polyprotein }\end{array}$ & $\begin{array}{l}\% \\
\text { Similarity }\end{array}$ \\
\hline 1 & $\begin{array}{l}\text { Neuro- } \\
\text { modulin }\end{array}$ & $\begin{array}{l}\text { Chain A, } \\
\text { Cryoem } \\
\text { Structure Of } \\
\text { Immature } \\
\text { Zika Virus }\end{array}$ & 5U4W_A & 182 to 203 & 54 \\
\hline 2 & Nestin & polyprotein & AMM43326.1 & 3097 to 3215 & 45 \\
\hline 3 & Bombesin & polyprotein & ANK57896.1 & 756 to 827 & 42 \\
\hline 4 & Galanin & $\begin{array}{l}\text { Polyprotein, } \\
\text { partial }\end{array}$ & ANF29038.1 & 440 to 476 & 48 \\
\hline 5 & $\begin{array}{l}\text { Calcium } \\
\text { binding } \\
\text { protein }\end{array}$ & polyprotein & AHF49785.1 & 2872 to 2967 & 41 \\
\hline
\end{tabular}

Alternation from the normal cell state could cause biochemical and physiological changes in host signalling, transmission, metabolic alteration, inflammation, autoantibody (autoimmunity) and neuropathy. Increased rates of Guillain-Barré [39, 40] an aberrant physiological function affecting cardiac rhythm [41] have been associated with Zika V infection. The in silico search is the beginning of identifying host-pathogenic mimics.
The functionally relevant step after this is to publish the wet experimental data of confirmed mimics. These similarityoverlapping regions will be interesting to analyse by wet experimentation in cell culture and animal experimental models to better understand the mechanism of host-pathogen interaction and to identify potential targets for drug and vaccine discovery.

\section{Conclusion:}

This paper identified Zika viral Polyprotein C (virulent factor) sequence similarities to Human proteins Neuromodulin, Nestin, Bombesin, Galanin, Calcium-binding proteins all of which are significant in host functions in the nervous tissue. Multiple sequence alignment identified a distinct region of the polyprotein C (959-1659 aa which encompasses Non-structural protein 1, 2A, $2 \mathrm{~B}$ and Serine protease NS3) having identities to all the five human proteins of this study. This region has critical functions involved in immune evasion, pathogenesis and viral replication. In summary, the identified regions of human nerve proteins and the Zika Viral polyprotein C warrants further experimentation on their role in the pathogenesis.

\section{Competing interests:}

The authors declare that they have no competing interests.

\section{Authors' contributions:}

PM and LS conceived the present study, design, interpretation of data and preparation of the manuscript. JL, LV, PDS, SS and RS were involved in interpretation and preparation of the manuscript.

\section{Acknowledgements:}

We acknowledge the support of Nireekshana ACET and CODEWEL for this project.

\section{References:}

[1] http://www.who.int/csr/disease/zika/en/

[2] Merfeld E et al. Wiley Interdiscip. Rev. Dev. Biol. 2017, 6. [PMID: 2838380]

[3] Beckham JD et al. JAMA Neurol. 2016, 73:875. [PMID: 27183312]

[4] Mladinich MC et al. Mbio. 2017, 8:e00952. [PMID: 28698279]

[5] Broutet N et al. N. Engl. J. Med. 2016, 374:1506. [PMID: 26959308]

[6] Tappe D et al. Med. Microbiol. Immunol. 2016, 205:269. [PMID: 26702627]

[7] Hamel R et al. J. Virol. 2015, 89:8880. [PMID: 26085147]

[8] Stanfield BA \& Luftig MA. F1000 Research. 2017, 6:386.

[9] Briken V. Curr. Drug Targets. 2008, 9:150. [PMID: 18288966]

[10] Lucchese G \& Kanduc D. Autoimmun Rev. 2016, 15:801. [PMID: 27019049]

[11] Yu X et al. J. Proteome Res. 2015, 14:1920. [PMID: 25739981]

[12] Suneetha LM et al. Neurochem. Res. 2003, 28:1393. [PMID: 12945534]

[13] Su MA et al. J. Immunol. 2012, 188:4906. [PMID: 22490868]

[14] Raju R et al. Neurochem. Res. 2011, 36:766. [PMID: 21234675]

[15] Vardhini D et al. Infect. Genet. Evol. 2004, 4:21. [PMID: 15019586]

[16] Gutlapalli VR et al. Bioinformation. 2015, 11:517. [PMID: 26770024] 
[17] Rolfe AJ et al. Cell Biosci. 2016, 6:42. [PMID: 27293547]

[18] Lucchese G \& Kanduc D. Autoimmun. Rev. 2016, 15:801. [PMID: 27019049]

[19] Lucchese G \& Kanduc D. Virus Adapt. Treat. 2017, 9:1.

[20] Suneetha L et al. 2018.

[21] Altschul SF et al. Nucleic Acids Res. 1997, 25:3389. [PMID: 9254694]

[22] Uhlen M et al. Science. 2015, 347:1260419. [PMID: 25613900]

[23] Sievers F et al. Mol. Syst. Biol. 2011, 7:539. [PMID: 21988835]

[24] Wilson MR et al. J. Biol. Chem. 2017.

[25] Rigden DJ et al. Nucleic Acids Res. 2016, 44:D1 [PMID: 26740669]

[26] Kosik KS et al. Neuron. 1988, 1:127. [PMID: 3272162]

[27] LaBate ME \& Skene JH. Neuron. 1989, 3:299. [PMID: 2641999]

[28] Gilyarov AV. Neurosci. Behav. Physiol. 2008, 38:165. [PMID: 18197384]

[29] Noronha L et al. Mem. Inst. Oswaldo Cruz. 2016, 111:287. [PMID: 27143490]

[30] Bersani M et al. FEBS Lett. 1991, 283:189. [PMID: 1710578]

[31] Kaplan LM et al. Proc. Natl. Acad. Sci. 1988, 85:1065. [PMID:
2448788]

[32] Counts SE et al. Cell. Mol. Life Sci. 2008, 65:1842. [PMID: 18500641]

[33] Tucci V et al. J. Glob. Infect. Dis. 2017, 9:151. [PMID: 29302150]

[34] Haeseleer F et al. J. Biol. Chem. 2000, 275:1247. [PMID: 10625670]

[35] Haeseleer F et al. Biochem. Biophys. Res. Commun. 2002, 290:615. [PMID: 11785943]

[36] Christel C \& Lee A. Biochim. Biophys. Acta. 2012, 1820:1243. [PMID: 22223119]

[37] https://www.ncbi.nlm.nih.gov/Structure/mmdb/mmdbsr v.cgi?uid $=5 \mathrm{u} 4 \mathrm{w}$.

[38] Asif A et al. Zika Viral Immunol. 2017, 30:682 [PMID: 29028178]

[39] Styczynski AR et al. PLoS Negl. Trop. Dis. 2017, 11:e0005869. [PMID: 28854206]

[40] https://www.cdc.gov/mmwr/volumes/65/wr/mm6534e1 .htm [PMID: 27711040]

[41] Gold CA et al. JAMA Neurol. 2016, 73:905. [PMID: 27272118]

Edited by $P$ Kangueane

Citation: Marsakatla et al. Bioinformation 14(5): 194-200 (2018) License statement: This is an Open Access article which permits unrestricted use, distribution, and reproduction in any medium, provided the original work is properly credited. This is distributed under the terms of the Creative Commons Attribution License 